Article

\title{
Preparation of gold clusters on metal oxides by deposition-precipitation with microwave drying and their catalytic performance for $\mathrm{CO}$ and sulfide oxidation
}

\author{
Ayako Taketoshi a,b, Tamao Ishida a,b, Hironori Ohashi c, Tetsuo Honma d, Masatake Haruta a,b,e,* \\ a Research Center for Gold Chemistry, Graduate School of Urban Environmental Sciences, Tokyo Metropolitan University, 1-1 Minami-osawa, Hachioji, \\ Tokyo 192-0397, Japan \\ b Department of Applied Chemistry, Graduate School of Urban Environmental Sciences, Tokyo Metropolitan University, 1-1 Minami-osawa, Hachioji, Tokyo \\ 192-0397, Japan \\ c Faculty of Symbiotic Systems Science, Fukushima University, 1 Kanayagawa, Fukushima, Fukushima 960-1296, Japan \\ d Japan Synchrotron Radiation Research Institute (JASRI), 1-1-1 Kouto, Sayo, Hyogo 679-5198, Japan \\ e Gold Catalysis Research Center, Dalian Institute of Chemical Physics, Chinese Academy of Sciences, Dalian 116023, Liaoning, China
}

\section{A R T I C L E I N F O}

\section{Article history:}

Received 29 July 2017

Accepted 6 September 2017

Published 5 November 2017

\section{Keywords:}

Gold nanoparticles

Gold clusters

Microwave

CO oxidation

Aerobic oxidation

\begin{abstract}
A B S T R A C T
Gold clusters and small nanoparticles supported on metal oxides could be prepared by deposition-precipitation followed by microwave irradiation as a drying method and then calcination. The drying method influenced the size of the Au particles. Au(III) was partly reduced during conventional oven drying, resulting in $\mathrm{Au}$ aggregates. In contrast, $\mathrm{Au}(\mathrm{III})$ was preserved during microwave drying owing to rapid and uniform heating, and the Au diameter was minimized to $1.4 \mathrm{~nm}$ on $\mathrm{Al}_{2} \mathrm{O}_{3}$. This method can be applied to several metal oxide supports having different microwave absorption efficiencies, such as $\mathrm{MnO}_{2}, \mathrm{Al}_{2} \mathrm{O}_{3}$, and $\mathrm{TiO}_{2}$. These catalysts exhibited higher catalytic activities for $\mathrm{CO}$ oxidation at low temperature and for selective aerobic oxidation of sulfide than those prepared by conventional methods.
\end{abstract}

(C) 2017, Dalian Institute of Chemical Physics, Chinese Academy of Sciences. Published by Elsevier B.V. All rights reserved.

\section{Introduction}

Since the discovery of catalysis by gold, unique catalytic performances of $\mathrm{Au}$ nanoparticles (NPs) have been reported and are attracting growing interest. In particular, Au clusters, which are smaller than $2 \mathrm{~nm}$ in diameter, exhibit high catalytic properties distinct from those of Au NPs because Au clusters possess electronic structures different from those of Au NPs and at the same time provide increased fractions of edge and corner sites [1,2]. Therefore, the preparation methods for $\mathrm{Au}$ cluster catalysts have been intensively studied. In this point of view, atomically precise $\mathrm{Au}$ clusters such as a glutathi- one-protected $\mathrm{Au}_{25}$ cluster $\left(\mathrm{Au}_{25}(\mathrm{SG})_{18}\right)$ have been recently exploited as precursors and deposited on supports [3-10]. The thiolate and phosphine ligands are removed by calcination from $\mathrm{Au}$ surfaces, but the $\mathrm{Au}$ aggregation often takes place [6-9]. In addition, the ligand remained on the catalyst surface influenced the catalytic activity of Au even though the ligand was removed under detection limit [8-10]. Therefore, to prepare Au cluster catalysts without ligand is still demanded.

One of the most common preparation methods to obtain bare $\mathrm{Au}$ NPs on metal oxides is deposition-precipitation (DP); $\mathrm{Au}(\mathrm{OH})_{3}$ is precipitated exclusively onto metal oxide supports followed by calcination. The preparation conditions, such as $\mathrm{pH}$

* Corresponding author. Tel/Fax: +81-42-677-2852; E-mail: haruta-masatake@center.tmu.ac.jp

This work was supported by JSPS KAKENHI Grant Numbers JP26810098 and JP16K17943.

DOI: 10.1016/S1872-2067(17)62909-7 | http://www.sciencedirect.com/science/journal/18722067 | Chin. J. Catal., Vol. 38, No. 11, November 2017 
[11], Au precursors [12], calcination temperature [13,14], and treatment gas [15-18], influence the size of the Au particles, and many efforts have been made toward the optimization of these parameters. However, the drying process of the wet solid on which $\mathrm{Au}$ (III) is precipitated has not been well studied. Oven drying (OD) is usually used at approximately $120^{\circ} \mathrm{C}$ overnight [19-21]. Vacuum- [14] or freeze-drying (FD) [22] has also been exploited, but the reduction of $\mathrm{Au}(\mathrm{III})$ occurred to varying extents depending on the conditions [14]. The formation of $\mathrm{Au}(0)$ nuclei accelerates the aggregation of Au NPs during the subsequent calcination.

Microwave (MW) heating possesses some unique properties such as rapid, internal, and uniform heating. MW has been used for the formation of Au NPs [23] and the preparation of supported Au catalysts [24-34]. Simultaneous reduction of $\mathrm{Au}(\mathrm{III})$ to $\mathrm{Au}(0) \mathrm{NPs}$ and their deposition onto supports under MW irradiation has been performed in the co-presence of $\mathrm{Au}(\mathrm{III})$, supports, reductants, and/or protecting agents [24-30]. However, the diameter of the Au NPs generally exceeded $5 \mathrm{~nm}$ with few exceptions [24]. Meire et al. [31] used MW for the reduction of $\mathrm{Au}(\mathrm{OH})_{3}$ deposited on $\mathrm{TiO}_{2}$ prepared by $\mathrm{DP}$, but the obtained Au NPs were large and had wide size distributions. MW irradiation was also applied to the co-precipitation of $\mathrm{HAuCl}_{4}$ and nitrate salts of support metals in the presence of reductants and protecting agents [32-34], but the obtained catalysts showed low activity for CO oxidation $[32,33]$.

MW irradiation has also been applied to other purposes such as $\mathrm{MW}$-assisted deposition of metal precursors [35], ligand removal from $\mathrm{Au}_{25}(\mathrm{SG})_{18}$ on $\mathrm{Al}_{2} \mathrm{O}_{3}$ and $\mathrm{TiO}_{2}$ [5], and drying $[36,37]$. Wittanadecha et al. [36] used MW to prepare $\mathrm{Au} / \mathrm{C}$ by incipient wetness impregnation (IW) using $\mathrm{HAuCl}_{4}$. The catalyst contained $\mathrm{Au}(\mathrm{III})$ species together with small $\mathrm{Au}(0)$ particles $(<4 \mathrm{~nm})$. This result indicates that MW heating causes the reduction of $\mathrm{Au}(\mathrm{III})$ to $\mathrm{Au}(0)$ even in the absence of additional reductants. It is well known that the presence of chloride enhances the aggregation of Au NPs [38], and long MW irradiation time was also reported to cause the reduction of $\mathrm{Au}(\mathrm{III})$ $[31,36]$. Therefore, there is still room to optimize MW irradiation to preserve $\mathrm{Au}(\mathrm{III})$ as a drying method.

In this work, we studied the preparation of Au catalysts by DP combined with MW drying (MD). DP is generally used for neutral and basic supports, such as $\mathrm{Al}_{2} \mathrm{O}_{3}$ and $\mathrm{TiO}_{2}$, even though acidic supports, such as $\mathrm{SiO}_{2}$ and $\mathrm{MnO}_{2}$, can be used for DP using $\mathrm{Au}(\mathrm{en})_{2} \mathrm{Cl}_{3}$ as a precursor instead of $\mathrm{HAuCl}_{4}[12,19,39]$. Therefore, we chose $\mathrm{MnO}_{2}, \mathrm{Al}_{2} \mathrm{O}_{3}$, and $\mathrm{TiO}_{2}$ as supports. We found that $\mathrm{Au}(\mathrm{III})$ remained almost completely after the optimized MD conditions, whereas the reduction of Au occurred during OD when using $\mathrm{Al}_{2} \mathrm{O}_{3}$ and $\mathrm{TiO}_{2}$. The obtained catalysts exhibited remarkably higher catalytic activity than those prepared by DP with OD for the oxidation of $\mathrm{CO}$ and sulfide.

\section{Experimental}

\subsection{Materials}

Metal oxides, $\mathrm{Al}_{2} \mathrm{O}_{3}$ (Sumitomo Chemical, AKP-G015, $148 \mathrm{~m}^{2}$ $\mathrm{g}^{-1}$ ), and $\mathrm{TiO}_{2}$ (Nippon Aerosil, P-25, $50 \mathrm{~m}^{2} \mathrm{~g}^{-1}$ ) were pur- chased. $\mathrm{MnO}_{2}\left(98 \mathrm{~m}^{2} \mathrm{~g}^{-1}\right)$ was prepared in accordance with the previous literature [19]. As Au precursors, tetrachloroauric acid $\left(\mathrm{HAuCl}_{4} \cdot 4 \mathrm{H}_{2} \mathrm{O}\right)$ and bis(ethylenediamine) $\mathrm{Au}(\mathrm{III})$ trichloride $\left(\mathrm{Au}(\mathrm{en})_{2} \mathrm{Cl}_{3}\right)$ were purchased from Tanaka Kikinzoku Kogyo K.K. and Tri Chemical Laboratories Inc., respectively. Other reagents were purchased and used as received.

\subsection{Deposition of Au clusters onto metal oxides}

Gold on $\mathrm{Al}_{2} \mathrm{O}_{3}$ and $\mathrm{TiO}_{2}$ were prepared by DP with $\mathrm{HAuCl}_{4}$, because the points of zero charge of these metal oxides were above 7 ( $1 \mathrm{wt} \%$ Au loading) [40]. Briefly, the $\mathrm{pH}$ of the aqueous solution of $\mathrm{HAuCl}_{4}\left(2 \mathrm{mmol} \mathrm{L}^{-1}\right)$ was adjusted to 5 by adding aqueous $\mathrm{NaOH}$ solution, after the solution was heated to $70{ }^{\circ} \mathrm{C}$. Then, the support ( $2 \mathrm{~g}$ ) was dispersed into the solution, and the suspension was adjusted to $\mathrm{pH}=7$ by adding aqueous $\mathrm{NaOH}$ solution. After stirring at $70{ }^{\circ} \mathrm{C}$ for $1 \mathrm{~h}$, the solid was washed with $\mathrm{H}_{2} \mathrm{O}$, filtered, and divided into two groups: MD and OD. MW irradiation was performed by a Shikoku Instrumentation $\mu$ Reactor Ex, Max 1000 W, $2.45 \mathrm{GHz}$ for a few minutes depending on the type of support. For OD, the wet solid was dried in air at $120{ }^{\circ} \mathrm{C}$ overnight. The dried samples were denoted as drying method_only. The dried samples were reduced in a stream of 10 vol\% $\mathrm{H}_{2}$ in $\mathrm{N}_{2}$ at a flow rate of $50 \mathrm{~mL} \mathrm{~min}^{-1}$ at 300 ${ }^{\circ} \mathrm{C}$ for $1 \mathrm{~h}$, denoted as drying method_H $\mathrm{H}_{2}$. For comparison, FD was also tested under the same conditions except for the drying method. For FD, the wet solid was dried under vacuum overnight after cooling with liquid $\mathrm{N}_{2}$. Gold on $\mathrm{MnO}_{2}$ was prepared by $\mathrm{DP}$ with $\mathrm{Au}(\mathrm{en})_{2} \mathrm{Cl}_{3}$ as a precursor, because $\mathrm{MnO}_{2}$ is negatively charged in aqueous solution at $\mathrm{pH} 7$ (1 wt\% Au loading) [19]. The aqueous solution of $\mathrm{Au}(\mathrm{en})_{2} \mathrm{Cl}_{3}$ was heated to $70{ }^{\circ} \mathrm{C}$. After dispersing the $\mathrm{MnO}_{2}(2 \mathrm{~g})$, the $\mathrm{pH}$ of the suspension reached 10 . The $\mathrm{pH}$ was maintained at 10 during stirring at 70 ${ }^{\circ} \mathrm{C}$ for $1 \mathrm{~h}$. After washing with $\mathrm{H}_{2} \mathrm{O}$, the solid was filtered, dried by MW irradiation or in air at $120^{\circ} \mathrm{C}$ overnight, and then calcined in air at $300{ }^{\circ} \mathrm{C}$ for $4 \mathrm{~h}$, denoted as drying method_300.

\subsection{Characterization}

$\mathrm{Au}$ LIII-edge X-ray absorption fine structures (XAFS) were measured at BL14B2, SPring-8 (Hyogo, Japan) [41,42]. The XAFS samples were ground with or without boron nitride in an agate mortar and formed into pellets. The aqueous $\mathrm{Au}(\mathrm{en})_{2} \mathrm{Cl}_{3}$ solution was used as an $\mathrm{Au}(\mathrm{III})$ reference for $\mathrm{Au} / \mathrm{MnO}_{2}$. The $\mathrm{pH}$ of the solution was adjusted to 10 by adding aqueous $\mathrm{NaOH}$ solution. An incident beam from an $8 \mathrm{GeV}$ storage ring with a typical current of $99.5 \mathrm{~mA}$ was monochromatized by a $\mathrm{Si}$ double-crystal monochromator with a net plane of (311) for the $\mathrm{Au}$ LiII-edge. The XAFS spectra were recorded in transmission mode using ionization chambers for $\mathrm{Au} / \mathrm{Al}_{2} \mathrm{O}_{3}$ and $\mathrm{Au} / \mathrm{TiO}_{2}$ and in fluorescence mode using a 19-element Ge solid-state detector (19SSD) for $\mathrm{Au} / \mathrm{MnO}_{2}$. The spectral analysis was performed by the XAFS analysis software programs Athena and Artemis [43]. The extraction of the extended XAFS (EXAFS) oscillation from the spectra, normalization by edge-jump, and Fourier transformation were performed by Athena. The curve fitting analysis was performed in R-space by Artemis. In the 
curve-fitting analysis, the backscattering amplitude, the phase shift, and the mean-free path of the photoelectron were calculated by FEFF8.4 [44]. The number of neighboring atoms, the interatomic distance between the absorbed atom and the neighboring atom, the Debye-Waller factor, and the absorption edge energy were treated as fitting parameters. The intrinsic loss factor was obtained by the curve-fitting analysis of the EXAFS data of the Au foil.

Transmission electron microscope (TEM) and high-angle annular dark-field scanning TEM (HAADF-STEM) observations were performed using a JEOL JEM-3200FS operating at $300 \mathrm{kV}$.

${ }_{1}^{1} \mathrm{H}$ NMR spectra of the reaction solution of sulfide oxidation were measured on a JEOL ECS-300 spectrometer. Chemical shift values are expressed in ppm relative to internal tetramethylsilane.

The amount of excess surface oxygen was measured by iodometric titration [45]. A mixture of catalyst $(0.020 \mathrm{~g})$, KI (ca. $0.02 \mathrm{~g}$ ), and $0.1 \mathrm{~mol} \mathrm{~L}^{-1} \mathrm{HCl}$ aqueous solution $(5 \mathrm{~mL}$ ) was shaken for $5 \mathrm{~min}$. The residue was filtered and washed with $\mathrm{H}_{2} \mathrm{O}$ and ethanol. The amount of generated iodine was determined by titration with a sodium thiosulfate aqueous solution (10 $\mathrm{mmol} \mathrm{L}^{-1}$ ).

Diffuse reflectance infrared Fourier transform (DRIFT) spectra were obtained by JASCO, FT/IR-6100V equipped with a heat chamber (ST Japan, Model-HC500). The sample powder was pretreated in a flow of $\mathrm{N}_{2}\left(30 \mathrm{~mL} \mathrm{~min}^{-1}\right)$ at $250{ }^{\circ} \mathrm{C}$ for $1 \mathrm{~h}$. Then the sample was exposed to $10 \mathrm{vol} \% \mathrm{CO}$ in $\mathrm{He}(40 \mathrm{~mL}$ $\mathrm{min}^{-1}$ ) at $-180^{\circ} \mathrm{C}$ for $30 \mathrm{~min}$. DRIFT spectra were obtained by subtracting the background spectrum. After Au sites were saturated with a gas flow of $10 \mathrm{vol} \% \mathrm{CO} / \mathrm{He}$ mixture $(40 \mathrm{~mL}$ $\left.\mathrm{min}^{-1}\right)$, the catalyst was treated in a flow of $\mathrm{N}_{2}\left(30 \mathrm{~mL} \mathrm{~min}^{-1}\right)$ and the spectra were collected at $-180^{\circ} \mathrm{C}$.

\subsection{Catalytic tests}

\subsubsection{CO oxidation}

The catalytic test for CO oxidation was performed in a fixed-bed flow reactor containing $150 \mathrm{mg}$ of catalyst. The pretreatment was performed at $250{ }^{\circ} \mathrm{C}$ for $1 \mathrm{~h}$ in a stream of 20 vol\% $\mathrm{O}_{2}$ in $\mathrm{N}_{2}$ at a flow rate of $50 \mathrm{~mL} \mathrm{~min}^{-1}$. Then, the reaction gas containing $1 \mathrm{vol} \% \mathrm{CO}$ in air was passed through the reactor at a flow rate of $50 \mathrm{~mL} \mathrm{~min}^{-1}$ (space velocity of 20,000 $\mathrm{mL} \mathrm{h}^{-1}$ $\mathrm{g}_{\mathrm{cat}^{-1}}{ }^{-1}$. The effluent gas was analyzed by gas chromatography using an Ohkura Riken model-802 or a Shimadzu GC-8A with Gasukuropack 54 and Molecular Sieve 13X columns. The moisture content in the reaction gas was monitored by a dew-point meter (Air Liquid DPO-6), and the water concentrations were kept in the range of $20-100 \mathrm{ppm}$ at $T_{1 / 2}$, which is the temperature at $50 \%$ CO conversion in all experiments.

\subsubsection{Selective aerobic oxidation of sulfide}

To an autoclave was charged methylphenylsulfide $(118 \mu \mathrm{L}$, $1.0 \mathrm{mmol}), 1,2$-dichlorobenzene $(5.0 \mathrm{~mL}), \mathrm{Au} / \mathrm{MnO}_{2}(40 \mathrm{mg})$, and a magnetic stirring bar. The autoclave was purged and filled with $\mathrm{O}_{2}$ until the gauge pressure reached $0.5 \mathrm{MPa}$. The reaction mixture was stirred at $100{ }^{\circ} \mathrm{C}$ for $36 \mathrm{~h}$. The mixture was extracted with chloroform and filtered. The filtrate was analyzed by ${ }^{1} \mathrm{H}$ NMR using mesitylene as an internal standard.

\section{Results and discussion}

\subsection{Conditions of microwave drying for $\mathrm{Au} /$ metal oxide catalysts}

The DP with MD was applied to three kinds of metal oxide supports, $\mathrm{MnO}_{2}, \mathrm{Al}_{2} \mathrm{O}_{3}$, and $\mathrm{TiO}_{2}$, having different MW absorption efficiencies. Generally, black powders absorb MW efficiently [46,47]. The heating efficiency varies depending on crystal structure, lattice defects, and particle size even when the same oxide is used. To examine the MW absorption efficiency of the metal oxides used in this work, each dry metal oxide $(0.4 \mathrm{~g})$ was irradiated with $\mathrm{MW}$ at $500 \mathrm{~W}$. A radiation thermometer was set over the MW instrument to monitor the surface temperatures of the metal oxides. After $2 \mathrm{~min}$, the surface temperatures of $\mathrm{MnO}_{2}, \mathrm{Al}_{2} \mathrm{O}_{3}$, and $\mathrm{TiO}_{2}$ reached 91,68 , and $58^{\circ} \mathrm{C}$, respectively.

The irradiation conditions for $\mathrm{Au}(\mathrm{III})$ precursor $/ \mathrm{MO}_{x}$ were optimized by comparing the $\mathrm{CO}$ oxidation catalytic activity of $\mathrm{Au} / \mathrm{MO}_{x}$ without calcination for $\mathrm{MnO}_{2}$ and after $\mathrm{H}_{2}$ reduction for $\mathrm{Al}_{2} \mathrm{O}_{3}$ and $\mathrm{TiO}_{2}$ (Table 1). For $2 \mathrm{~g}$ of $\mathrm{Au} / \mathrm{MnO}_{2}$, the filtered wet solid was divided into four groups and irradiated with MW using power-fixed (Table 1, entries 1 and 2) or temperature-controlled modes (entries 3 and 4). When the power-fixed mode was applied, higher power gave higher actual temperature and catalytic activity (entry 2). In the temperature-controlled mode, the irradiation power varied automatically in the range of $0-1000 \mathrm{~W}$ to reach the target surface temperature. When the actual temperature was at approximately $100{ }^{\circ} \mathrm{C}$, the highest catalytic activity was obtained (entry 4). When $\mathrm{Au} / \mathrm{Al}_{2} \mathrm{O}_{3}$ and $\mathrm{Au} / \mathrm{TiO}_{2}$ were dried, the power-fixed mode was better than the temperature-controlled mode in terms of catalytic activity (entries 5 and 7). Higher irradiation power or longer time was required for $\mathrm{Al}_{2} \mathrm{O}_{3}$ and $\mathrm{TiO}_{2}$ than for $\mathrm{MnO}_{2}$ due to lower MW absorption efficiency.

In the previous reports, $\mathrm{Au}(\mathrm{III})$ was partially reduced to $\mathrm{Au}(0)$ during MW irradiation. Namely, Wittanadecha et al. [36] reported that $\mathrm{Au}(\mathrm{III})$ in $\mathrm{Au} / \mathrm{C}$ was reduced to $\mathrm{Au}(0)$ completely by MW irradiation at $800 \mathrm{~W}$ for 2 min. Kawamoto et al. [48] have reported that $\mathrm{Au}(\mathrm{OH})_{3}$ was converted into $\mathrm{Au}(0)$ under air flow via the dehydration of $\mathrm{Au}(\mathrm{OH})_{3}$ to $\mathrm{Au}_{2} \mathrm{O}_{3}$ and then the thermal decomposition of $\mathrm{Au}_{2} \mathrm{O}_{3}$ to $\mathrm{Au}(0)$ by TG/DTA analysis. Therefore, excessive heating may cause the reduction of $\mathrm{Au}(\mathrm{III})$. As shown in Table 1, the catalytic activity was decreased when the actual surface temperature exceed $100{ }^{\circ} \mathrm{C}$. It implied that overheating caused partial reduction of $\mathrm{Au}(\mathrm{III})$ and aggregation of $\mathrm{Au}$, leading to low catalytic activity. Consequently, the best result for each metal oxide was obtained when the surface temperature reached approximately $100{ }^{\circ} \mathrm{C}$ (entries 4, 5, and 7 ), and these optimum conditions were used in further studies.

\subsection{Effect of drying methods on chemical valence and particle size of $A u$}

\subsubsection{XANES}


Table 1

Effect of MD conditions for $\mathrm{Au} / \mathrm{MnO}_{2}, \mathrm{Au} / \mathrm{Al}_{2} \mathrm{O}_{3}$ and $\mathrm{Au} / \mathrm{TiO}_{2}$.

\begin{tabular}{|c|c|c|c|c|c|c|c|c|}
\hline \multirow{2}{*}{ Entry } & \multirow{2}{*}{ Catalyst } & \multicolumn{6}{|c|}{ MW irradiation conditions } & \multirow{2}{*}{$\begin{array}{c}\text { CO oxidation } \\
T_{1 / 2}\left({ }^{\circ} \mathrm{C}\right)\end{array}$} \\
\hline & & Power or target temp. & Ramp rate $\left({ }^{\circ} \mathrm{C} \mathrm{min}{ }^{-1}\right)$ & Holding (min) & Cycle (times) & Total (min) & Actual temp. $\left({ }^{\circ} \mathrm{C}\right)$ & \\
\hline 1 & $\mathrm{Au} / \mathrm{MnO}_{2}{ }^{\mathrm{a}}$ & $500 \mathrm{~W}$ & - & 2 & 3 & 6 & 85 & -28 \\
\hline 2 & & $600 \mathrm{~W}$ & - & 2 & 2 & 4 & 94 & -34 \\
\hline 3 & & $90^{\circ} \mathrm{C}$ & 25 & 1 & 1 & 4 & 110 & -45 \\
\hline 4 & & $80^{\circ} \mathrm{C}$ & 25 & 1 & 1 & 3 & 103 & -54 \\
\hline 5 & $\mathrm{Au} / \mathrm{Al}_{2} \mathrm{O}_{3} \mathrm{~b}$ & $600 \mathrm{~W}$ & - & 2 & 4 & 9 & 101 & 55 \\
\hline 6 & & $90^{\circ} \mathrm{C}$ & 25 & 1 & 2 & 7 & 84 & 61 \\
\hline 7 & $\mathrm{Au} / \mathrm{TiO}_{2} \mathrm{c}$ & $1000 \mathrm{~W}$ & - & 3 & 4 & 12 & 100 & -40 \\
\hline 8 & & $80^{\circ} \mathrm{C}$ & 25 & 1 & 4 & 15 & 88 & -31 \\
\hline
\end{tabular}

a $\mathrm{Au} / \mathrm{MnO}_{2} \mathrm{MW}$ _only was used for $\mathrm{CO}$ oxidation after pretreatment in air at $250{ }^{\circ} \mathrm{C}$ for $1 \mathrm{~h}$.

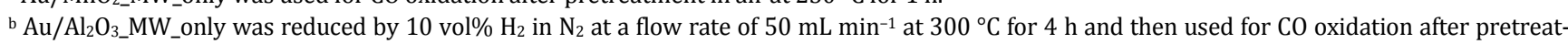
ment in air at $250^{\circ} \mathrm{C}$ for $1 \mathrm{~h}$.

${ }^{\mathrm{c}} \mathrm{Au} / \mathrm{TiO}_{2} \mathrm{MW}_{-}$only was reduced by 10 vol\% $\mathrm{H}_{2}$ in $\mathrm{N}_{2}$ at a flow rate of $50 \mathrm{~mL} \mathrm{~min}^{-1}$ at $100{ }^{\circ} \mathrm{C}$ for $1 \mathrm{~h}$ and then used for $\mathrm{CO}$ oxidation after pretreatment in air at $250^{\circ} \mathrm{C}$ for $1 \mathrm{~h}$.

XANES spectra were obtained in order to elucidate the chemical states of $\mathrm{Au}$ in the obtained catalysts. In the $\mathrm{Au}$ LIII-edge XANES spectra of MD_only and OD_only for $\mathrm{Au} / \mathrm{MnO}_{2}$, white lines were clearly observed at $11.92 \mathrm{keV}$ (Fig. 1(a)), suggesting that a major species was $\mathrm{Au}(\mathrm{III})$. The partial reduction of $\mathrm{Au}$ (III) on $\mathrm{MnO}_{2}$ was observed in both samples. For MD_only, the temperature inside the $\mathrm{MnO}_{2}$ wet solid probably exceeded $100{ }^{\circ} \mathrm{C}$ during MW irradiation, causing the reduction of $\mathrm{Au}(\mathrm{III})$ due to the high MW absorption efficiency of $\mathrm{MnO}_{2}$. After the calcination, the white line intensities significantly decreased, suggesting that most of $\mathrm{Au}(\mathrm{III})$ was reduced to $\mathrm{Au}(0)$ (Table 2).

For $\mathrm{Au} / \mathrm{Al}_{2} \mathrm{O}_{3}$ and $\mathrm{Au} / \mathrm{TiO}_{2}$, the white line intensities of MD_only and FD_only were almost the same as that of $\mathrm{Au}(\mathrm{OH})_{3}$ (Figs. 2 and 3). In contrast, the intensity of OD_only was decreased. The $\mathrm{Au}(0)$ contents were estimated to be $45 \%$ and $73 \%$ in $\mathrm{Au} / \mathrm{Al}_{2} \mathrm{O}_{3} \mathrm{OD}$ _only and $\mathrm{Au} / \mathrm{TiO}_{2}$ OD_only, respectively (Table 2). Therefore, MD prevented the reduction of $\mathrm{Au}(\mathrm{III})$ during drying even though the drying temperature was similar to $\mathrm{OD}$. After $\mathrm{H}_{2}$ reduction, $\mathrm{Au}(\mathrm{III})$ was completely reduced to $\mathrm{Au}(0)$ in all cases.

\subsubsection{EXAFS}

To discuss the size of Au particles by XAFS, the radial structure functions (RSFs) of $\mathrm{Au} / \mathrm{MnO}_{2}$ are shown in Fig. 1(b). The FT magnitude of the peaks at 2.52 and $3.00 \AA$ corresponding to $\mathrm{Au}-\mathrm{Au}$ interaction of all calcined $\mathrm{Au} / \mathrm{MnO}_{2}$ decreased compared with those of Au foil, indicating the formation of Au NPs and/or formation of amorphous Au. In particular, the FT magnitude for $\mathrm{Au}-\mathrm{Au}$ interaction in MD_250 was significantly lower than in MD_300, OD_250, and OD_300. Curve fitting analysis was performed to estimate the size of the Au NPs, and the EXAFS fitting parameters are shown in Table 3. The Debye-Waller factor, which accounts for the disorder in Au crystal, was almost the same as that of $\mathrm{Au}$ foil, excluding the presence of amorphous $\mathrm{Au}$. The coordination numbers (CNs) of the $\mathrm{Au}-\mathrm{Au}$ interaction of MD_250 and MD_300 were calculated to be 6.9 and 9.9 (Table 3). These values were 9.7 and 10.8 when only the $\mathrm{Au}(0)$ component was considered, and the estimated sizes from the CNs were 2.2 and $4.3 \mathrm{~nm}$, respectively (Table 2). In contrast, the CNs of OD_250 and OD_300 were nearly 12 for the $\mathrm{Au}(0)$
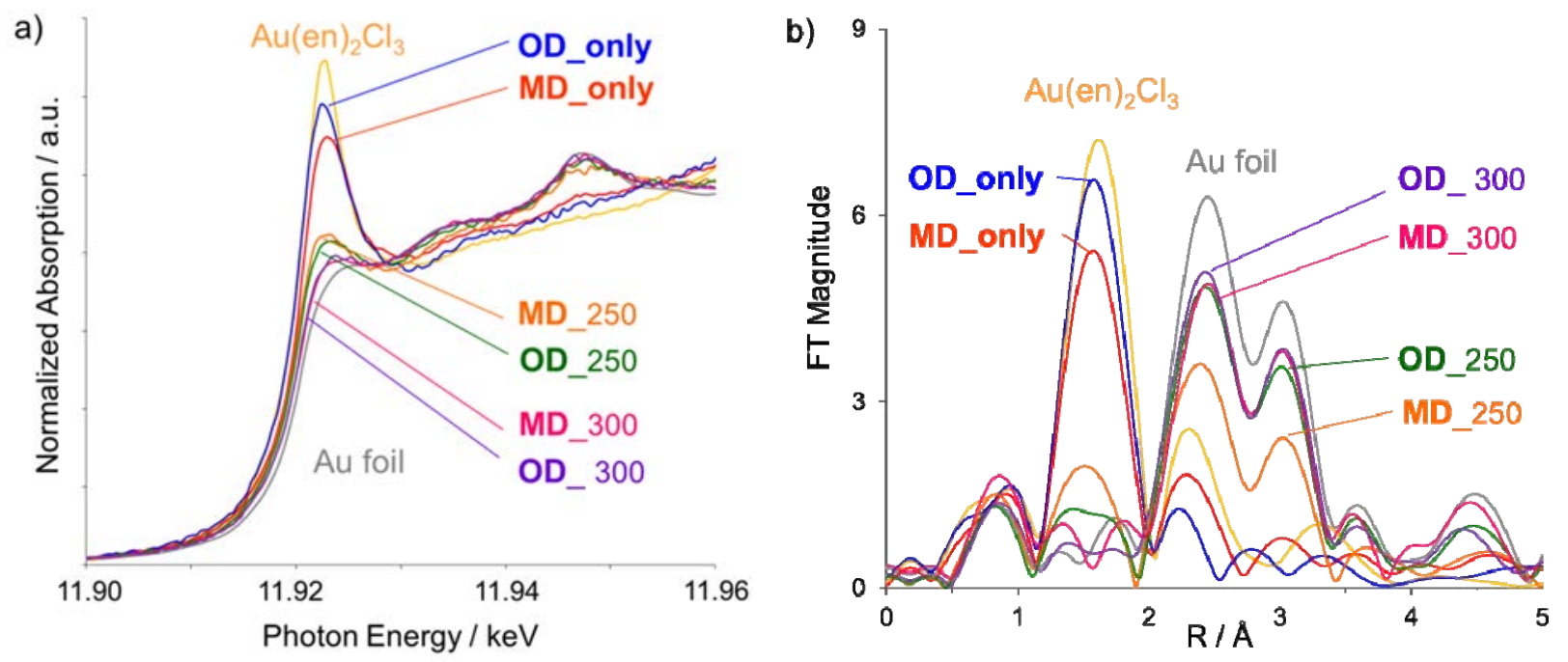

Fig. 1. (a) Au LIII-edge XANES spectra of $\mathrm{Au} / \mathrm{MnO}_{2}$ and (b) $\mathrm{Au} \mathrm{L}_{I I I}$-edge radial structure functions of $\mathrm{Au} / \mathrm{MnO}_{2}$. 
Table 2

Effect of drying and calcination conditions for physical properties of $\mathrm{Au} / \mathrm{MnO}_{2}, \mathrm{Au} / \mathrm{Al}_{2} \mathrm{O}_{3}, \mathrm{Au} / \mathrm{TiO}_{2}$ and their catalytic activity for $\mathrm{CO}$ oxidation.

\begin{tabular}{|c|c|c|c|c|c|c|}
\hline \multirow{2}{*}{ Entry } & \multirow{2}{*}{ Catalyst } & \multirow{2}{*}{$\begin{array}{c}\text { Drying and } \\
\text { calcination conditions }^{\mathrm{a}}\end{array}$} & \multicolumn{2}{|c|}{ XAFS } & \multirow{2}{*}{$\begin{array}{c}\text { HAADF } \\
\text { diameter of } \mathrm{Au}(\mathrm{nm})\end{array}$} & \multirow{2}{*}{$\begin{array}{c}\text { CO oxidation } \\
T_{1 / 2}\left({ }^{\circ} \mathrm{C}\right)^{\mathrm{b}}\end{array}$} \\
\hline & & & $\mathrm{Au}^{0}(\%)$ & Estimated size $(\mathrm{nm})$ & & \\
\hline 1 & $\mathrm{Au} / \mathrm{MnO}_{2}$ & MD_only & 29 & - & - & - \\
\hline 2 & & OD_only & 14 & - & - & - \\
\hline 3 & & MD_250 & 71 & 2.2 & $2.1 \pm 0.8$ & -54 \\
\hline 4 & & OD_250 & 80 & $>5$ & $4.0 \pm 7.1$ & -2 \\
\hline 5 & & MD_300 & 92 & 4.3 & $4.3 \pm 2.9$ & 26 \\
\hline 6 & & OD_300 & 91 & $>5$ & $6.8 \pm 7.9$ & 74 \\
\hline 7 & $\mathrm{Au} / \mathrm{Al}_{2} \mathrm{O}_{3}$ & MD_only & 0 & - & - & - \\
\hline 8 & & FD_only & 0 & - & - & - \\
\hline 9 & & OD_only & 45 & - & $2.3 \pm 1.8$ & - \\
\hline 10 & & MD_H ${ }_{2}$ & 100 & 1.6 & $1.4 \pm 1.2$ & 68 \\
\hline 11 & & FD_H ${ }_{2}$ & 100 & 1.9 & $1.9 \pm 1.3$ & 72 \\
\hline 12 & & $\mathrm{OD}_{-} \mathrm{H}_{2}$ & 100 & 2.3 & $3.2 \pm 2.6$ & 87 \\
\hline 13 & $\mathrm{Au} / \mathrm{TiO}_{2}$ & MD_only & 6 & - & - & - \\
\hline 14 & & OD_only & 73 & - & $2.1 \pm 0.9$ & - \\
\hline 15 & & MD_H ${ }_{2}$ & 100 & 2.7 & $2.2 \pm 0.8$ & -42 \\
\hline 16 & & $\mathrm{OD}_{-} \mathrm{H}_{2}$ & 100 & 3.2 & $2.9 \pm 1.1$ & -13 \\
\hline
\end{tabular}

a Drying method_300 was calcined in air at $300{ }^{\circ} \mathrm{C}$ for 4 h. Drying method_ $\mathrm{H}_{2}$ was reduced by $10 \mathrm{vol} \% \mathrm{H}_{2}$ in $\mathrm{N}_{2}$ at a flow rate of $50 \mathrm{~mL} \mathrm{~min}^{-1}$ at $300{ }^{\circ} \mathrm{C}$ for $1 \mathrm{~h}$.

${ }^{\text {b }} \mathrm{CO}$ oxidation was performed after pretreatment at $250{ }^{\circ} \mathrm{C}$ for $1 \mathrm{~h}$ in a stream of $20 \mathrm{vol} \% \mathrm{O}_{2}$ in $\mathrm{N}_{2}$ at a flow rate of $50 \mathrm{~mL} \mathrm{~min}^{-1}$.
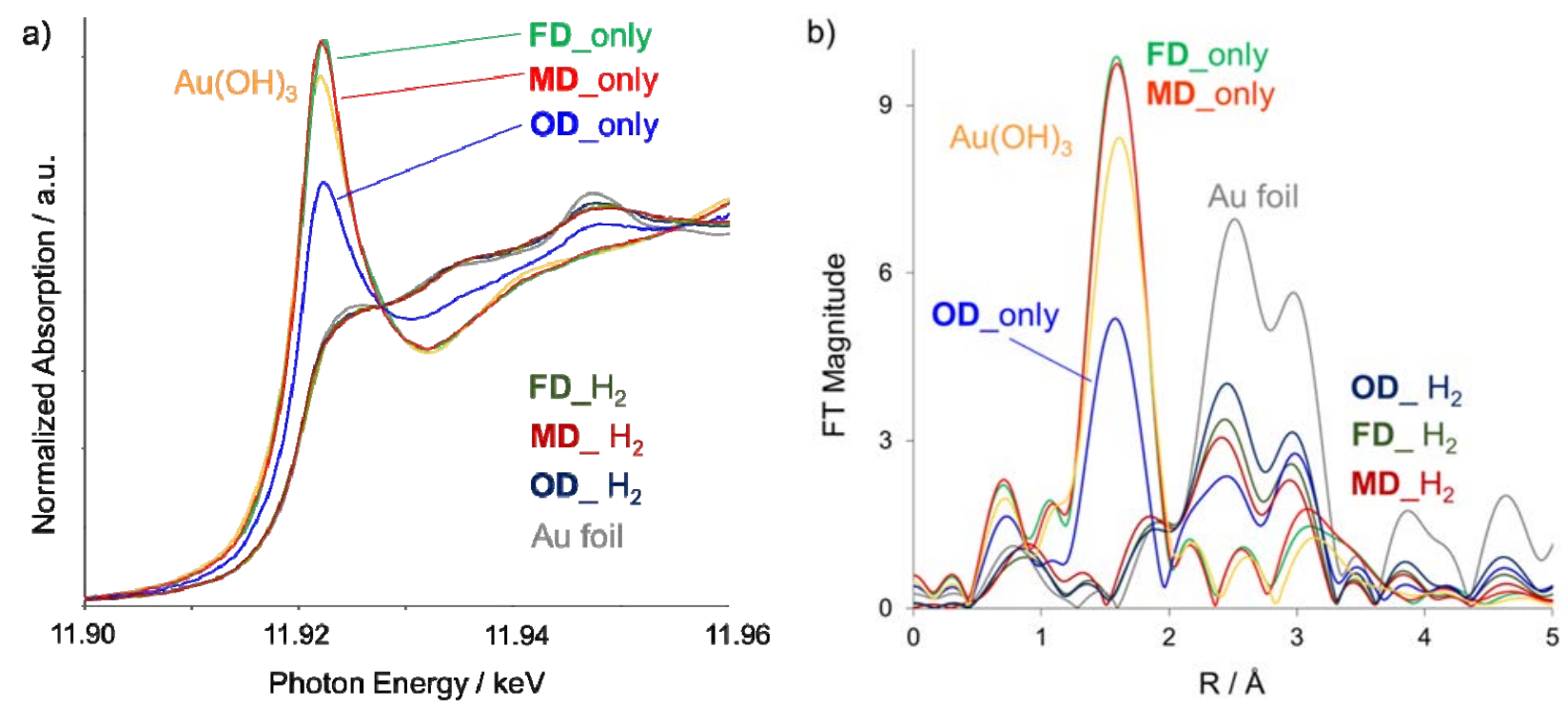

Fig. 2. (a) $\mathrm{Au} \mathrm{L}_{\mathrm{III}}$-edge XANES spectra of $\mathrm{Au} / \mathrm{Al}_{2} \mathrm{O}_{3}$ and (b) $\mathrm{Au} \mathrm{LIII-edge} \mathrm{radial} \mathrm{structure} \mathrm{functions} \mathrm{of} \mathrm{Au} / \mathrm{Al}_{2} \mathrm{O}_{3}$.

component as well as bulk. Even if the $\mathrm{CN}$ is 11 , the estimated size from the $\mathrm{CN}$ exceeds $5 \mathrm{~nm}$. Therefore, the mean diameters of these catalysts were larger than at least $5 \mathrm{~nm}$.

For both $\mathrm{Au} / \mathrm{Al}_{2} \mathrm{O}_{3}$ and $\mathrm{Au} / \mathrm{TiO}_{2}$, the FT magnitude of $\mathrm{Au}-\mathrm{Au}$ interaction of $\mathrm{MD}_{-} \mathrm{H}_{2}$ was lower than in $\mathrm{OD}_{-} \mathrm{H}_{2}$, as observed in $\mathrm{Au} / \mathrm{MnO}_{2}$; smaller $\mathrm{Au}$ NPs were formed in $\mathrm{MD}_{-} \mathrm{H}_{2}$ than in OD_H2 (Figs. 2(b), 3(b) and Tables 2, 3). Accordingly, the smallest $\mathrm{Au}$ clusters, with a diameter of $1.6 \mathrm{~nm}$ estimated by XAFS, were deposited on $\mathrm{Al}_{2} \mathrm{O}_{3}$ using $\mathrm{MD}$ followed by $\mathrm{H}_{2}$ reduction $\left(\mathrm{Au} / \mathrm{Al}_{2} \mathrm{O}_{3} \mathrm{MD}_{2} \mathrm{H}_{2}\right)$. We also compared $\mathrm{MD}$ with $\mathrm{FD}$ for $\mathrm{Au} / \mathrm{Al}_{2} \mathrm{O}_{3}$. Although $\mathrm{Au}(\mathrm{III})$ was preserved during both drying methods, the $\mathrm{Au}$ particle size of $\mathrm{MD}_{-} \mathrm{H}_{2}$ was slightly smaller than that of FD_H2.

As judged by the Au particle size, MD is the most effective drying method. Although $\mathrm{Au}(0)$ was formed in both
$\mathrm{Au} / \mathrm{MnO}_{2}$ MD_only and $\mathrm{Au} / \mathrm{MnO}_{2}$ OD_only, smaller $\mathrm{Au}$ NPs were obtained for MD_250 than for OD_250, which is likely due to different $\mathrm{Au}$ particle sizes forming after MD and OD. It is likely that $\mathrm{Au}(\mathrm{III})$ species were highly dispersed by MD, giving $\mathrm{Au}$ cluster catalysts. When $\mathrm{Al}_{2} \mathrm{O}_{3}$ and $\mathrm{TiO}_{2}$ were used as supports, OD caused the reduction of $\mathrm{Au}(\mathrm{III})$ to form $\mathrm{Au}(0)$ nuclei and facilitated the aggregation of $\mathrm{Au}(0)$ particles. Once $\mathrm{Au}(0)$ nuclei are formed, Au(III) would be preferentially reduced on the nuclei to form Au NPs during the subsequent calcination. MD can be performed in a much shorter time than OD, preventing the reduction of $\mathrm{Au}(\mathrm{III})$. FD also prevents the reduction of $\mathrm{Au}(\mathrm{III})$, but $\mathrm{Au}$ particles are aggregated compared with MD after $\mathrm{H}_{2}$ reduction. One possible explanation is that structures of adsorbed $\mathrm{Au}(\mathrm{III})$ species may change depending on the drying conditions. Moreau et al. [49] proposed the adsorption 
a)

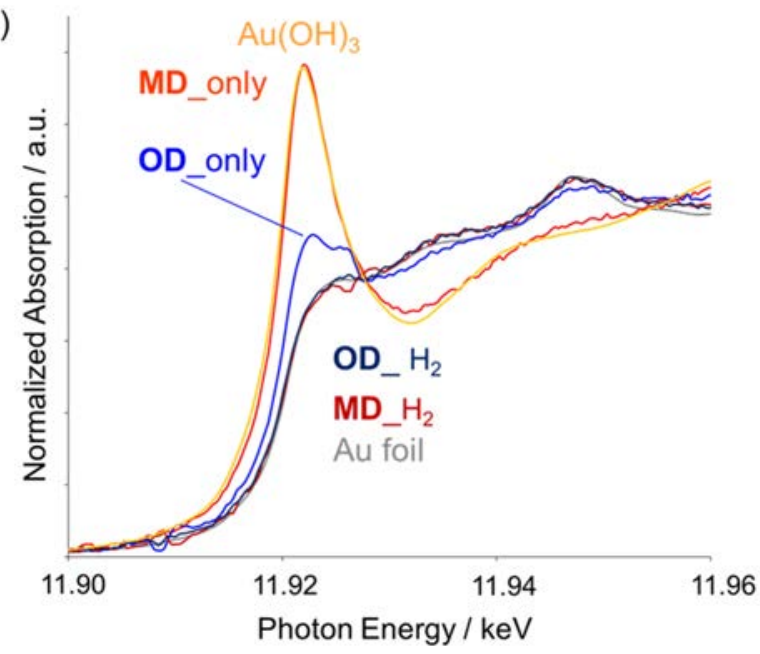

b)

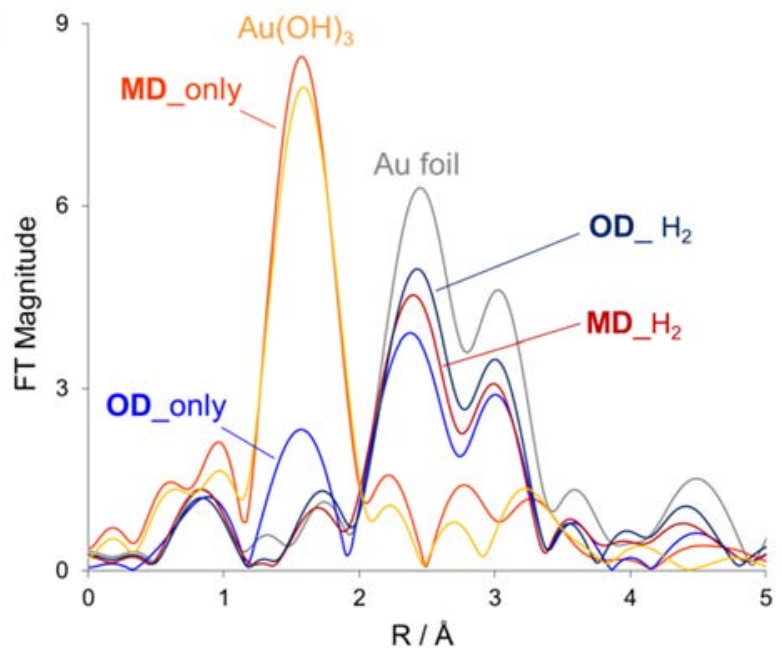

Fig. 3. (a) Au LIII-edge XANES spectra of $\mathrm{Au} / \mathrm{TiO}_{2}$ and (b) $\mathrm{Au} \mathrm{L}_{\mathrm{III}}$-edge radial structure functions of $\mathrm{Au} / \mathrm{TiO}_{2}$.

mechanisms of $\mathrm{Au}(\mathrm{OH})_{3}$ on $\mathrm{TiO}_{2}$. At $\mathrm{pH}>6, \mathrm{Au}(\mathrm{OH})_{3}$ might interact with the surface hydroxy groups of metal oxides and be adsorbed by dehydration. As the dehydration progressed, $\mathrm{Au}_{2} \mathrm{O}_{3}$, which is unstable, was formed. Although $\mathrm{Au}_{2} \mathrm{O}_{3}$ was not observed in $\mathrm{MD}$ and $\mathrm{FD}$, difference in the adsorbed $\mathrm{Au}(\mathrm{OH})_{x}$ structure may affect the stability of $\mathrm{Au}(\mathrm{III})$. A previous report also proposed that the structure of $\mathrm{Au}(\mathrm{OH})_{3}$ was a linear polymer bridged by $\mathrm{OH}$ groups between $\mathrm{Au}(\mathrm{III})$ [48]. Therefore, another possibility is that the chain length of $\left[\mathrm{Au}(\mathrm{OH})_{3}\right]_{n}$, i.e., the size of $\left[\mathrm{Au}(\mathrm{OH})_{3}\right]_{n}$ particles, obtained by MD and FD may be different, although the size of $\mathrm{Au}(\mathrm{III})$ species cannot be confirmed by XAFS due to amorphous $\mathrm{Au}(\mathrm{OH})_{3}$.

\subsubsection{HAADF-STEM}

The HAADF-STEM images of $\mathrm{Au} / \mathrm{MnO}_{2}$ are shown in Fig. 4. In both MD_only and OD_only, Au particles were scarcely found, but a few Au clusters ca. $1 \mathrm{~nm}$ in diameter were observed (Fig. 4(a) and (b)). After MD_only and OD_only were pretreated in air at $250{ }^{\circ} \mathrm{C}$ or calcined in air at $300{ }^{\circ} \mathrm{C}$ for $4 \mathrm{~h}$, Au NPs were formed and clearly observed. The mean diameters of $\mathrm{Au}$ for MD_250 and MD_300 were estimated to be 2.1 and $4.3 \mathrm{~nm}$ (Fig. 4(d) and (h)). These values were consistent with XAFS and smaller than those for OD_250 and OD_300, respectively. Careful HAADF-STEM observation revealed large Au NPs (>30 nm) in OD_250 and OD_300, which resulted in a broader size distribution (Fig. 4(f) and (j)). It should be mentioned that MD can prevent the aggregation of Au during calcination to give smaller Au particles than OD in spite of the fact that partial reduction of $\mathrm{Au}(\mathrm{III})$ occurred during both MD and OD.

As shown in Figs. 5 and 6, Au NPs were observed in OD_only but not in $\mathrm{MD}$ _only for $\mathrm{Au} / \mathrm{Al}_{2} \mathrm{O}_{3}$ and $\mathrm{Au} / \mathrm{TiO}_{2}$. After reduction by $\mathrm{H}_{2}$, the Au NPs on both supports were aggregated to larger

Table 3

EXAFS fit parameters for $\mathrm{Au} / \mathrm{MnO}_{2}{ }^{\mathrm{a}}, \mathrm{Au} / \mathrm{Al}_{2} \mathrm{O}_{3}$, , and $\mathrm{Au} / \mathrm{TiO}_{2}{ }^{\mathrm{c}}$.

\begin{tabular}{|c|c|c|c|c|c|c|c|}
\hline Entry & Sample & & Shells & $\mathrm{CN}^{\mathrm{d}}$ & $R(\AA){ }^{\mathrm{e}}$ & $\sigma^{2}\left(\AA^{2}\right)^{\mathrm{f}}$ & $R_{\text {factor }}{ }^{\mathrm{g}}$ \\
\hline 1 & $\mathrm{Au}$ foil & & $\mathrm{Au}-\mathrm{Au}$ & 12.0 & $2.865 \pm 0.002$ & $0.0081 \pm 0.0003$ & 0.0007 \\
\hline 2 & $\mathrm{Au}(\mathrm{en})_{2} \mathrm{Cl}_{3}$ & & $\mathrm{Au}-\mathrm{N}$ & 4.0 & $2.023 \pm 0.017$ & $0.0034 \pm 0.0025$ & 0.0126 \\
\hline 3 & $\mathrm{Au} / \mathrm{MnO}_{2}$ & MD_250 & $\mathrm{Au}-\mathrm{Au}$ & 6.9 & $2.848 \pm 0.010$ & $0.0087 \pm 0.0004$ & 0.0141 \\
\hline 4 & & & $\mathrm{Au}-\mathrm{N}$ & 1.0 & $1.982 \pm 0.020$ & $0.0013 \pm 0.0029$ & \\
\hline 5 & & OD_250 & $\mathrm{Au}-\mathrm{Au}$ & 9.8 & $2.858 \pm 0.005$ & 0.00869 (share) & 0.0020 \\
\hline 6 & & & $\mathrm{Au}-\mathrm{N}$ & 0.8 & $2.013 \pm 0.018$ & $0.0041 \pm 0.0028$ & \\
\hline 7 & & MD_300 & $\mathrm{Au}-\mathrm{Au}$ & 9.9 & $2.863 \pm 0.004$ & 0.00869 (share) & 0.0073 \\
\hline 8 & & OD_300 & $\mathrm{Au}-\mathrm{Au}$ & 10.4 & $2.856 \pm 0.007$ & 0.00869 (share) & 0.0017 \\
\hline 9 & $\mathrm{Au} / \mathrm{Al}_{2} \mathrm{O}_{3}$ & MD_H ${ }_{2}$ & $\mathrm{Au}-\mathrm{Au}$ & 8.8 & $2.811 \pm 0.004$ & $0.0123 \pm 0.0006$ & 0.0023 \\
\hline 10 & & $\mathrm{FD}_{-} \mathrm{H}_{2}$ & $\mathrm{Au}-\mathrm{Au}$ & 9.2 & $2.824 \pm 0.004$ & $0.0118 \pm 0.0006$ & 0.0022 \\
\hline 11 & & OD_H $\mathrm{H}_{2}$ & $\mathrm{Au}-\mathrm{Au}$ & 9.8 & $2.836 \pm 0.002$ & $0.0107 \pm 0.0003$ & 0.0007 \\
\hline 12 & $\mathrm{Au} / \mathrm{TiO}_{2}$ & MD_H ${ }_{2}$ & $\mathrm{Au}-\mathrm{Au}$ & 10.1 & $2.832 \pm 0.005$ & $0.0100 \pm 0.0008$ & 0.0032 \\
\hline 13 & & $\mathrm{OD}_{-} \mathrm{H}_{2}$ & $\mathrm{Au}-\mathrm{Au}$ & 10.4 & $2.848 \pm 0.005$ & $0.0094 \pm 0.0008$ & 0.0028 \\
\hline
\end{tabular}

a $k^{3}$ : $k$-range $=2-10 \AA^{-1}, r$-range $=1.9-3.4 \AA$ for $\mathrm{Au}-\mathrm{Au}$ and 1.1-1.9 $\AA$ for $\mathrm{Au}-\mathrm{N}$. Intrinsic loss factor, $S_{0}^{2}=0.83(\mathrm{Au}-\mathrm{Au})$ from $\mathrm{Au}$ foil and $0.90(\mathrm{Au}-\mathrm{N})$ from $\mathrm{Au}(\mathrm{en})_{2} \mathrm{Cl}_{3}$.

${ }^{\mathrm{b}} k^{3}$ : $k$-range $=2-11 \AA^{-1}, r$-range $=2.0-3.3 \AA$ for $\mathrm{Au}-\mathrm{Au}$. Intrinsic loss factor, $S_{0}^{2}=0.81(\mathrm{Au}-\mathrm{Au})$ from $\mathrm{Au}$ foil.

${ }^{c} k^{3}: k$-range $=2-10 \AA^{-1}, r$-range $=1.95-3.35 \AA$ for $\mathrm{Au}$-Au. Intrinsic loss factor, $S_{0}^{2}=0.84(\mathrm{Au}-\mathrm{Au})$ from $\mathrm{Au}$ foil.

d First shell coordination number.

e Bond length.

${ }^{f}$ Debye-Waller factor.

g Goodness-of-fit index. 

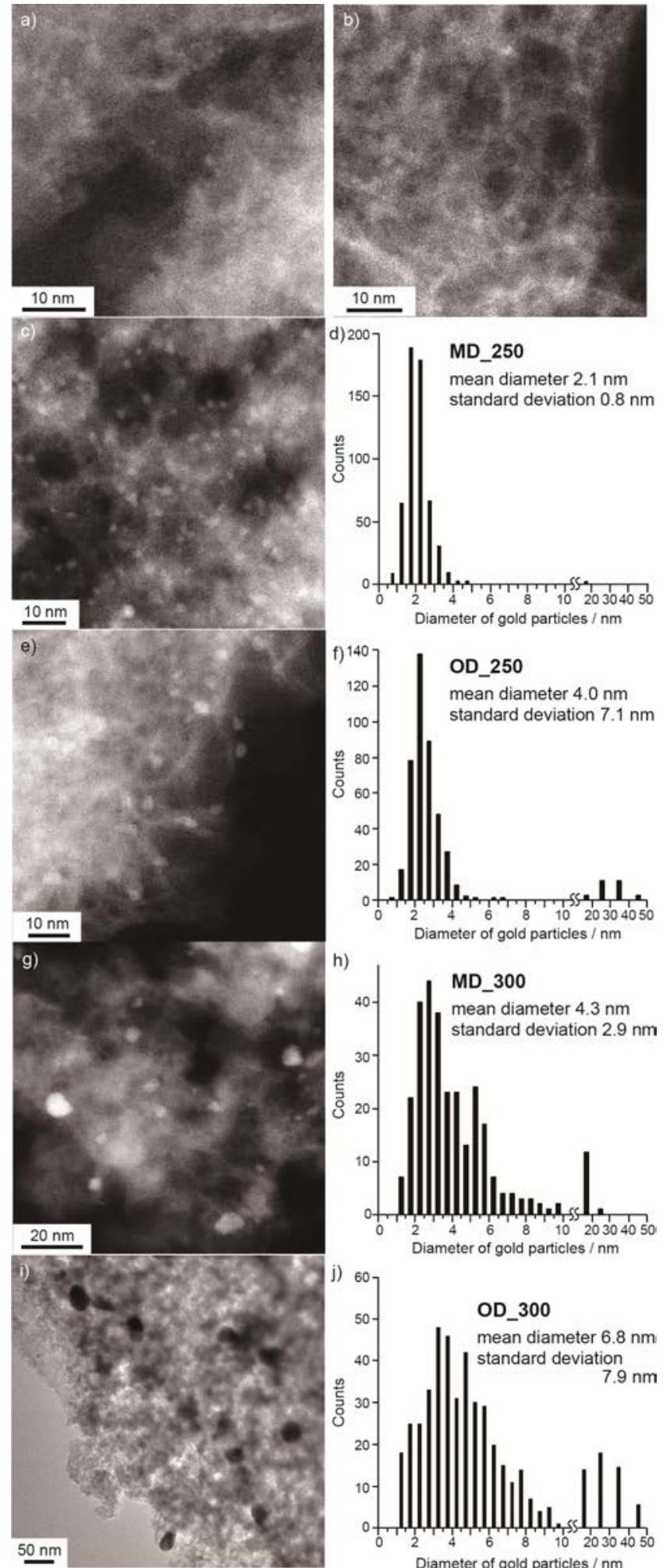

Fig. 4. HAADF-STEM images of $\mathrm{Au} / \mathrm{MnO}_{2}$ (a) MD_only, (b) OD_only, (c) MD_250, (e) OD_250, and (g) MD_300, TEM image of (i) OD_300, and distributions of the diameter of Au NPs in (d) MD_250, (f) OD_250, (h) MD_300, and (j) OD_300.

NPs than that of OD_only. For MD and FD, cluster-sized particles were obtained even after reduction by $\mathrm{H}_{2}$. The size of $\mathrm{Au} / \mathrm{Al}_{2} \mathrm{O}_{3} \mathrm{MD}_{-} \mathrm{H}_{2}$ was estimated to be $1.4 \mathrm{~nm}$, which was in

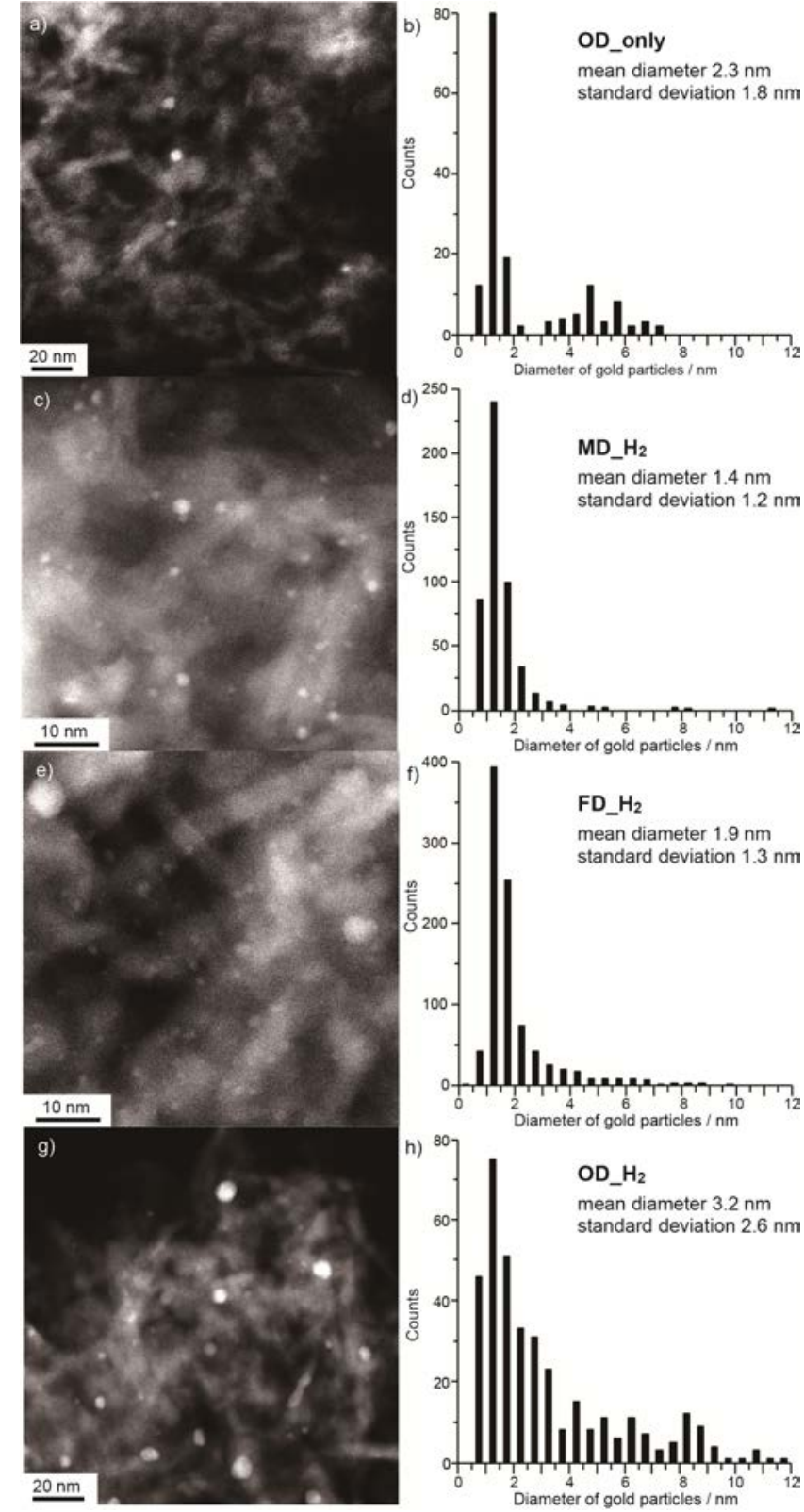

Fig. 5. HAADF-STEM images and distributions of the diameter of $\mathrm{Au}$ NPs in $\mathrm{Au} / \mathrm{Al}_{2} \mathrm{O}_{3}$ (a, b) OD_only, (c, d) $\mathrm{MD}_{-} \mathrm{H}_{2}$, (e, f) $\mathrm{FD}_{-} \mathrm{H}_{2}$, and (g, h) OD_H $\mathrm{H}_{2}$.

accordance with XAFS results (Fig. 5).

\subsection{CO oxidation}

Fig. 7 shows the results of $\mathrm{CO}$ oxidation on $\mathrm{Au} / \mathrm{MnO}_{2}$ and $\mathrm{MnO}_{2} . \mathrm{MnO}_{2}$ is also catalytically active for $\mathrm{CO}$ oxidation without the deposition of $\mathrm{Au}$, but the $T_{1 / 2}$ was $103^{\circ} \mathrm{C}$. With the deposition of $\mathrm{Au}$ NPs, the $T_{1 / 2}$ of all $\mathrm{Au} / \mathrm{MnO}_{2}$ decreased by more than $30{ }^{\circ} \mathrm{C}$. The catalytic activities of MD_250 and OD_250 were much higher than that of $\mathrm{MnO}_{2}$. MD_250 exhibited the highest catalytic activity. The $T_{1 / 2}$ of MD_250 was $-54{ }^{\circ} \mathrm{C}$, which was approximately $50{ }^{\circ} \mathrm{C}$ lower than that of OD_250. Although the catalytic activity decreased after calcination due to the aggregation of $\mathrm{Au}$, the catalytic activity of MD_300 was remarkably 

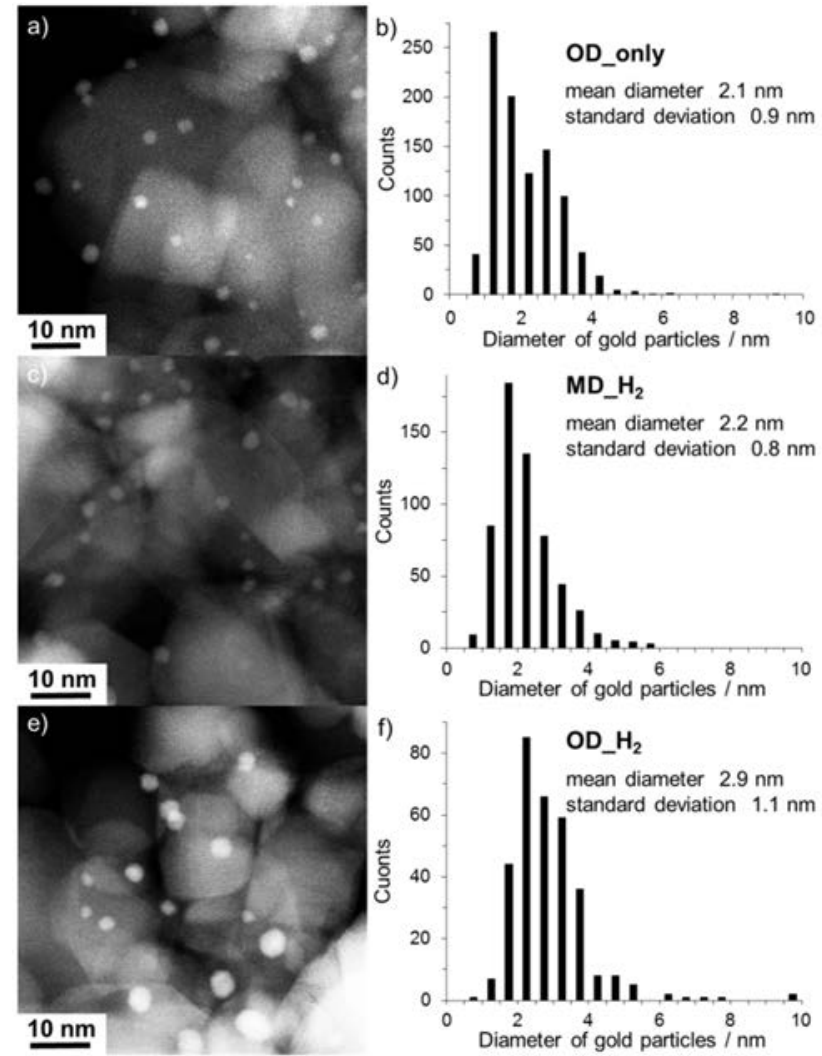

Fig. 6. HAADF-STEM images and distributions of the diameter of gold $\mathrm{NPs}$ in $\mathrm{Au} / \mathrm{TiO}_{2}$ (a, b) OD_only, (c, d) MD_H $\mathrm{H}_{2}$, and (e, f) OD_H 2 .

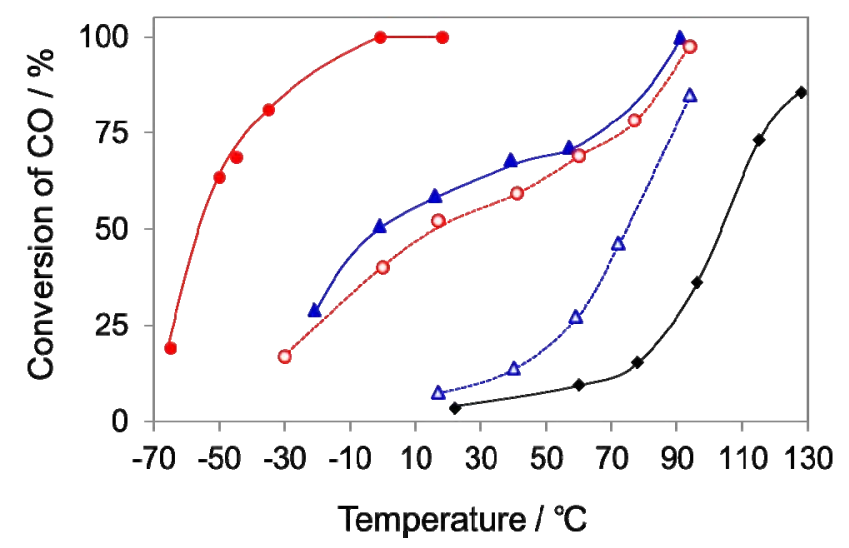

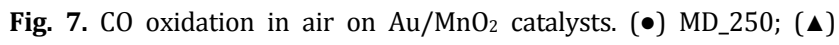
OD_250; (O) MD_300; $(\Delta)$ OD_300; $(\bullet) \mathrm{MnO}_{2}$.

higher than that of $\mathrm{MnO}_{2}$ and OD_300; the $T_{1 / 2}$ was $26^{\circ} \mathrm{C}$ (Table 2).

Fig. 8 shows the results of $\mathrm{CO}$ oxidation on $\mathrm{Au} / \mathrm{Al}_{2} \mathrm{O}_{3}$ and $\mathrm{Au} / \mathrm{TiO}_{2}$. The catalytic activity increased with a decrease in the size of $\mathrm{Au}$ as in the case of $\mathrm{Au} / \mathrm{MnO}_{2}$. The catalytic activities of both $\mathrm{MD}_{-} \mathrm{H}_{2}$ were higher than those of $\mathrm{OD}_{-} \mathrm{H}_{2}$ (Table 2). The catalyst that possessed the highest ratio of Au clusters exhibited the highest catalytic activity (MD_H ${ }_{2}$ ). MD also gave better results for $\mathrm{Au} / \mathrm{Al}_{2} \mathrm{O}_{3}$ than $\mathrm{OD}$ and $\mathrm{FD}$ did. As a result, MD can be used to deposit small $\mathrm{Au}$ particles regardless of the type of metal oxide support and Au precursor, leading to high catalytic

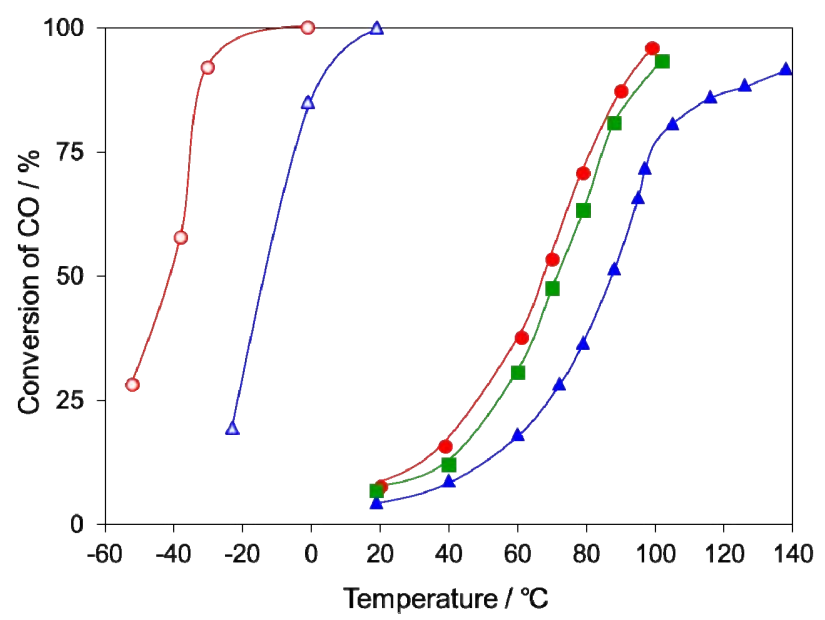

Fig. 8. $\mathrm{CO}$ oxidation in air on $\mathrm{Au} / \mathrm{TiO}_{2}(\mathrm{O}) \mathrm{MD}_{-} \mathrm{H}_{2}$ and $(\Delta) \mathrm{OD}_{-} \mathrm{H}_{2}$, and $\mathrm{Au} / \mathrm{Al}_{2} \mathrm{O}_{3}(\bullet) \mathrm{MD}_{-} \mathrm{H}_{2},(\boldsymbol{\bullet}) \mathrm{FD}_{-} \mathrm{H}_{2}$, and $(\boldsymbol{\Delta}) \mathrm{OD}_{-} \mathrm{H}_{2}$.

activity.

To further elucidate the difference in catalytic activity between $\mathrm{Au}$ clusters and NPs, DRIFT spectra of $\mathrm{Au} / \mathrm{Al}_{2} \mathrm{O}_{3} \mathrm{MD}_{-} \mathrm{H}_{2}$ and $\mathrm{Au} / \mathrm{Al}_{2} \mathrm{O}_{3} \mathrm{OD}_{-} \mathrm{H}_{2}$ were obtained using $\mathrm{CO}$ as a probe molecule (Fig. 9). $\mathrm{Al}_{2} \mathrm{O}_{3}$ also adsorbed $\mathrm{CO}$ and the corresponding peaks were observed at 2183, 2152, and $2132 \mathrm{~cm}^{-1}$. After $\mathrm{Au}$ deposition, the additional peaks were observed. In the case of $\mathrm{Au} / \mathrm{Al}_{2} \mathrm{O}_{3} \mathrm{MD}_{-} \mathrm{H}_{2}$, the peaks corresponding to the adsorbed $\mathrm{CO}$ were observed at 2122 and $2093 \mathrm{~cm}^{-1}$. These were assigned as $\mathrm{Au}^{\delta+}-\mathrm{CO}$ and $\mathrm{Au}^{0}-\mathrm{CO}$, respectively [50,51]. On the other hand, in the case of $\mathrm{Au} / \mathrm{Al}_{2} \mathrm{O}_{3} \mathrm{OD}_{-} \mathrm{H}_{2}$, the peak at $2093 \mathrm{~cm}^{-1}$ ascribed to $\mathrm{Au}^{0}$ was observed while the peak for $\mathrm{Au}^{\delta+}$ was negligible. It is widely accepted that cationic Au species are present at the perimeter. Therefore, the presence of $\mathrm{Au}^{\delta+}$ in large amount for $\mathrm{Au} / \mathrm{Al}_{2} \mathrm{O}_{3} \mathrm{MD}_{-} \mathrm{H}_{2}$ suggested the markedly increased $\mathrm{Au}$ perim-

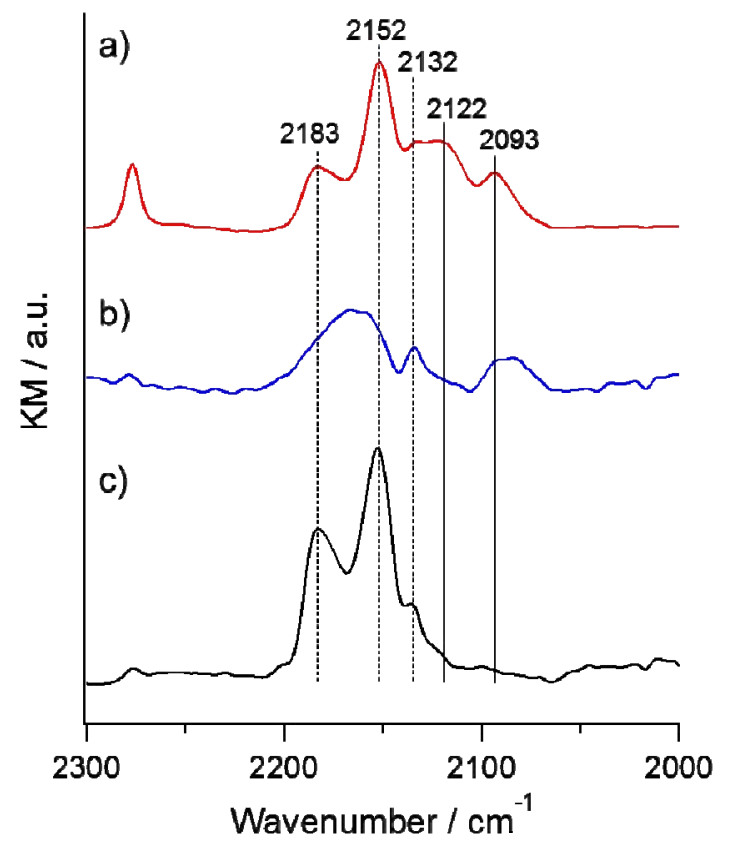

Fig. 9. DRIFT spectra of $\mathrm{CO}$ adsorbed on (a) $\mathrm{Au} / \mathrm{Al}_{2} \mathrm{O}_{3} \mathrm{MD}_{-} \mathrm{H}_{2}$, (b) $\mathrm{Au} / \mathrm{Al}_{2} \mathrm{O}_{3} \mathrm{OD}_{-} \mathrm{H}_{2}$, and (c) $\mathrm{Al}_{2} \mathrm{O}_{3}$. 
eter atoms. The perimeter interface is known as the active sites for CO oxidation [2], but one of our authors [52] and Lu et al. [53] reported that the amount of cationic Au species and catalytic activity did not directly correlate. Therefore, the contribution of change in the oxidation state of Au might not be a determination factor. It is likely that the improved activity of $\mathrm{Au}$ clusters in this paper is ascribed to markedly increased $\mathrm{Au}-\mathrm{MO}_{x}$ interface, edge and corner sites for $\mathrm{CO}$ adsorption.

\subsection{Selective aerobic oxidation of sulfide}

We recently reported that $\mathrm{MnO}_{x}$ and $\mathrm{Au} / \mathrm{MnO}_{x}$ catalyzed the selective aerobic oxidation of sulfides to sulfoxides [19]. Since the active species is $\mathrm{MnO}_{x}$ in this reaction, $\mathrm{MnO}_{x}$ with higher amounts of excess surface oxygen has higher catalytic activity, and the deposition of $\mathrm{Au}$ enhanced the catalytic activity of $\mathrm{MnO}_{x}$ owing to the enhanced activation of oxygen at the interface between $\mathrm{Au}$ and $\mathrm{MnO}_{x}$. Therefore, minimizing the size of $\mathrm{Au}$ particles increases the active $\mathrm{Au}-\mathrm{MnO}_{x}$ interface and will offer highly active catalysts. The catalytic activities for the selective oxidation of sulfide to sulfoxide were also tested (Table 4). With the deposition of Au NPs, sulfide conversion and sulfoxide selectivity were improved as previously reported (entries 4 and 5). An increase in excess surface oxygen by the deposition of $\mathrm{Au}$ was confirmed by iodometric titration. The amount of excess surface oxygen was not directly related to catalytic activity for $\mathrm{Au} / \mathrm{MnO}_{2}$. This is due to slight differences in excess surface oxygen among $\mathrm{Au} / \mathrm{MnO}_{2}$. Given that $\mathrm{MD}_{-}$only containing $\mathrm{Au}(\mathrm{III})$ and Au clusters of $1 \mathrm{~nm}$ in diameter exhibited the highest catalytic activity, $\mathrm{Au}(\mathrm{III})$ also contributes to the activation of oxygen at the $\mathrm{Au}(\mathrm{III})-\mathrm{MnO}_{2}$ interface, and highly dispersed $\mathrm{Au}(\mathrm{III})$ and Au clusters markedly improved the catalytic activity. Although there was no difference in $\mathrm{Au}$ particle size between MD_only and OD_only in the TEM results, the yield was improved by using MD_only. Au(III) species derived from $\mathrm{Au}(\mathrm{en})_{2} \mathrm{Cl}_{3}$ may present not only as mononuclear but also polynuclear complexes as is the case for $\left[\mathrm{Au}(\mathrm{OH})_{3}\right]_{n}$. Accordingly, the size of $\mathrm{Au}(\mathrm{III})$ species might be different between MD_only and OD_only and affect the catalytic activity because of the different lengths of perimeter interfaces between $\mathrm{Au}$ and $\mathrm{MnO}_{2}$.

Table 4

Selective aerobic oxidation of methyl phenyl sulfide by $\mathrm{Au} / \mathrm{MnO}_{2}$. ${ }^{\mathrm{a}}$

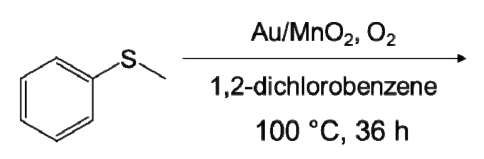

1

\begin{tabular}{lccccc}
\hline \multirow{2}{*}{ Entry } & Catalyst & $\begin{array}{c}\text { Excess surface oxygen } \\
\left(\mathrm{mg} \mathrm{g}^{-1}\right)\end{array}$ & $\begin{array}{c}\text { Conv. } \\
(\%)\end{array}$ & \multicolumn{2}{c}{ Yield (\%) $^{\mathrm{b}}$} \\
\hline 1 & MD_only & 42 & 65 & 64 & 1 \\
2 & OD_only & 43 & 56 & 54 & 2 \\
3 & $\mathrm{MD}^{2} 300$ & 41 & 59 & 57 & 2 \\
4 & $\mathrm{OD}_{3} 300$ & 41 & 52 & 50 & 2 \\
5 & $\mathrm{MnO}_{2}$ & 36 & 30 & 26 & 4 \\
\hline
\end{tabular}

a Reaction conditions: sulfide (1.0 mmol), catalyst (40 mg), 1,2-dichlorobenzene $(5 \mathrm{~mL}), p_{0_{2}}\left(0.5 \mathrm{MPa}\right.$, gauge pressure), $100{ }^{\circ} \mathrm{C}, 36 \mathrm{~h}$.

b Determined by ${ }^{1} \mathrm{H}$ NMR spectroscopy using mesitylene as an internal standard.

\section{Conclusions}

Small Au NPs and clusters could be deposited on metal oxides by deposition-precipitation followed by MW irradiation and calcination. The catalysts prepared by MD exhibited higher activities for both gas and liquid phase oxidations than those prepared by OD and FD. The MD can be applied to several metal oxides regardless of the efficiency of MW absorption and performed in a much shorter time than OD. This method is very simple and convenient because there is no need to prepare clusters beforehand and to remove ligands and protecting agents. (1) In the case of $\mathrm{Au} / \mathrm{MnO}_{2}$, although $\mathrm{Au}(\mathrm{III})$ was partly reduced to $\mathrm{Au}(0)$ after $\mathrm{MD}$ and $\mathrm{OD}$, smaller $\mathrm{Au}$ NPs were obtained by MD than by OD, which lead to high catalytic activity for sulfide oxidation. (2) In the case of $\mathrm{Au} / \mathrm{Al}_{2} \mathrm{O}_{3}$ and $\mathrm{Au} / \mathrm{TiO}_{2}$, MD can be performed at a relatively lower temperature than OD and more quickly than FD. Therefore, the reduction of $\mathrm{Au}(\mathrm{III})$ and the aggregation of $\mathrm{Au}(0)$ particles can be prevented during drying, yielding Au cluster catalysts. In particular, the $\mathrm{Au}$ particle size was minimized to $1.4 \mathrm{~nm}$ on $\mathrm{Al}_{2} \mathrm{O}_{3}$ using MD followed by reduction with $\mathrm{H}_{2}$.

\section{Acknowledgments}

The synchrotron radiation experiments were performed at the BL14B2 in SPring-8 with the approval of JASRI (2015B1781, 2015B1883, and 2016A1521). We thank Mr. E. Watanabe of Tokyo Metropolitan University for helping with TEM observation.

\section{References}

[1] A. Taketoshi, M. Haruta, Chem. Lett., 2014, 43, 380-387.

[2] T. Ishida, H. Koga, M. Okumura, M. Haruta, Chem. Rec., 2016, 16, 2278-2293.

[3] G. Li, R. C. Jin, Acc. Chem. Res., 2013, 46, 1749-1758.

[4] S. Yamazoe, T. Yoskamtorn, S. Takano, S. Yadnum, J. Limtrakul, T. Tsukuda, Chem. Rec., 2016, 16, 2338-2348.

[5] M. Farrag, Microporous Mesoporous Mater., 2016, 232, 248-255.

[6] Y. Negishi, Y. Matsuura, R. Tomizawa, W. Kurashige, Y. Niihori, T. Takayama, A. Iwase, A. Kudo, J. Phys. Chem. C, 2015, 119, 11224-11232.

[7] C. Liu, J. Y. Zhang, J. H. Huang, C. L. Zhang, F. Hong, Y. Zhou, G. Li, M. Haruta, ChemSusChem, 2017, 10, 1976-1980.

[8] B. Zhang, J. Fang, J. G. Li, J. J. Lau, D. Mattia, Z. Y. Zhong, J. P. Xie, N. Yan, Chem. Asian J., 2016, 11, 532-539.

[9] R. H. Adnan, G. G. Andersson, M. I. J. Polson, G. F. Metha, V. B. Golovko, Catal. Sci. Technol., 2015, 5, 1323-1333.

[10] T. Yoskamtorn, S. Yamazoe, R. Takahata, J. Nishigaki, A. Thivasasith, J. Limtrakul, T. Tsukuda, ACS Catal., 2014, 4, 3696-3700.

[11] M. Haruta, J. New Mater. Electrochem. Systems, 2004, 7, 163-172.

[12] R. Zanella, L. Delannoy, C. Louis, Appl. Catal. A, 2005, 291, 62-72.

[13] M. Daté, Y. Ichihashi, T. Yamashita, A. Chiorino, F. Boccuzzi, M. Haruta, Catal. Today, 2002, 72, 89-94.

[14] R. Zanella, S. Giorgio, C.-H. Shin, C. R. Henry, C. Louis, J. Catal., 2004, 222, 357-367.

[15] D. Cunningham, S. Tsubota, N. Kamijo, M. Haruta, Res. Chem. Intermed., 1993, 19, 1-13.

[16] S. Tsubota, D. A. H. Cunningham, Y. Bando, M. Haruta, Stud. Surf. 


\section{Graphical Abstract}

Chin. J. Catal., 2017, 38: 1888-1898 doi: 10.1016/S1872-2067(17)62909-7

Preparation of gold clusters on metal oxides by deposition-precipitation with microwave drying and their catalytic performance for $\mathrm{CO}$ and sulfide oxidation

Ayako Taketoshi, Tamao Ishida, Hironori Ohashi, Tetsuo Honma, Masatake Haruta*

Tokyo Metropolitan University, Japan;

Fukushima University, Japan;

Japan Synchrotron Radiation Research Institute (JASRI), Japan;

Dalian Institute of Chemical Physics, Chinese Academy of Sciences, China

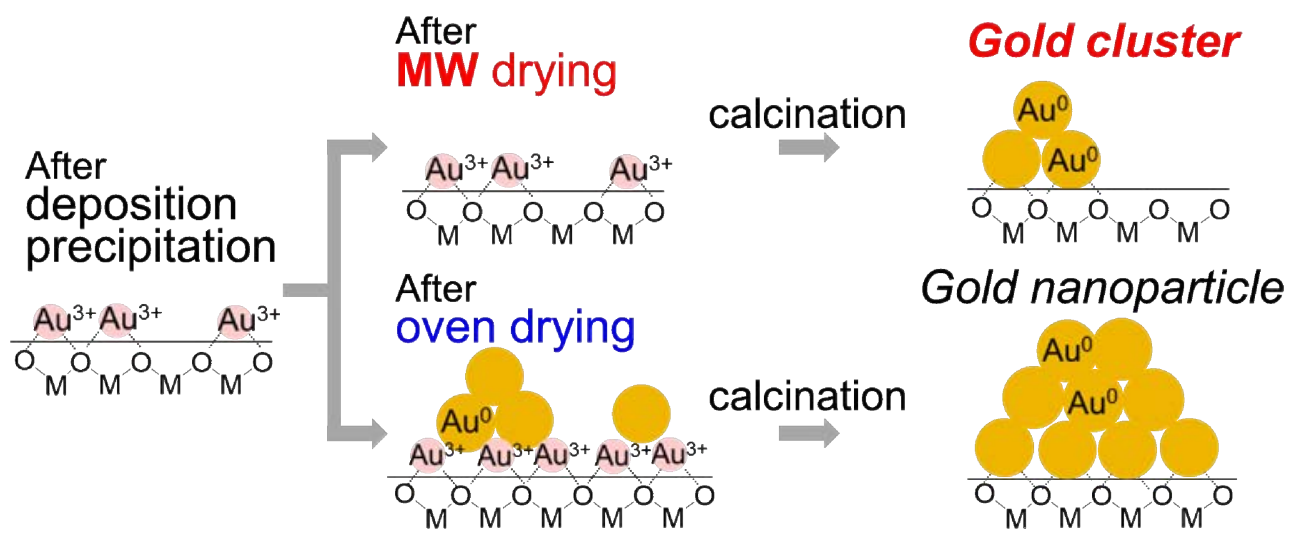

Small gold nanoparticles and clusters could be deposited on metal oxides by deposition-precipitation followed by microwave drying and calcination. The MW drying can be applied to several metal oxides regardless of the MW absorption efficiency.

Sci. Catal., 1995, 91, 227-235.

[17] B. Schumacher, V. Plzak, M. Kinne, R. J. Behm, Catal. Lett., 2003, 89, 109-114.

[18] R. Zanella, C. Louis, Catal. Today, 2005, 107-108, 768-777.

[19] A. Taketoshi, P. Concepción, H. García, A. Corma, M. Haruta, Bull. Chem. Soc. Jpn., 2013, 86, 1412-1418.

[20] Q. He, S. J. Freakley, J. K. Edwards, A. F. Carley, A. Y. Borisevich, Y. Mineo, M. Haruta, G. J. Hutchings, C. J. Kiely, Nat. Commun., 2016, $7,12905$.

[21] Y. Iizuka, Y. Hiragi, H. Yakushiji, T. Miura, Chin. J. Catal., 2016, 37, 1712-1720.

[22] A. K. Sinha, S. Seelan, T. Akita, S. Tsubota, M. Haruta, Appl. Catal. A, 2003, 240, 243-252.

[23] P. Y. Zhang, B. Zhang, R. Shi, Front. Environ. Sci. Eng. China, 2009, 3, 281-288.

[24] J. M. Campelo, T. D. Conesa, M. J. Gracia, M. J. Jurado, R. Luque, J. M. Marinas, A. A. Romero, Green Chem., 2008, 10, 853-858.

[25] Q. T. Hu, Z. B. Gan, X. W. Zheng, Q. F. Lin, B. F. Xu, A. H. Zhao, X. Zhang, Superlattices Microstruct., 2011, 49, 537-542.

[26] Y. Wang, J. G. Yu, W. Xiao, Q. Li, J. Mater. Chem. A, 2014, 2, 3847-3855.

[27] P. Sharma, G. Darabdhara, T. M. Reddy, A. Borah, P. Bezboruah, P. Gogoi, N. Hussain, P. Sengupta, M. R. Das, Catal. Commun., 2013, 40, 139-144.

[28] K. S. Prasad, H. B. Noh, S. S. Reddy, A. E. Reddy, Y. B. Shim, Appl. Catal. A, 2014, 476, 72-77.

[29] M. D. L. R. Peralta, U. Pal, R. S. Zeferio, ACS Appl. Mater. Interfaces, 2012, 4, 4807-4816.

[30] P. Kundu, N. Singhania, G. Madras, N. Ravishankar, Dalton Trans., 2012, 41, 8762-8766.

[31] M. Meire, P. Tack, K. De Keukeleere, L. Balcaen, G. Pollefeyt, F. Vanhaecke, L. Vincze, P. Van Der Voort, I. Van Driessche, P. Lom- mens, Spectrochim. Acta B, 2015, 110, 45-50.

[32] G. Glaspell, L. Fuoco, M. S. El-Shall, J. Phys. Chem. B, 2005, 109, 17350-17355.

[33] G. Glaspell, H. M. A. Hassan, A. Elzatahry, L. Fuoco, N. R. E. Radwan, M. S. El-Shall, J. Phys. Chem. B, 2006, 110, 21387-21393.

[34] W. Zhu, S. N. Xiao, D. Q. Zhang, P. J. Liu, H. J. Zhou, W. R. Dai, F. F. Liu, H. X. Li, Langmuir, 2015, 31, 10822-10830.

[35] S. Shironita, T. Takasaki, T. Kamegawa, K. Mori, H. Yamashita, Catal. Lett., 2009, 129, 404-407.

[36] W. Wittanadecha, N. Laosiripojana, A. Ketcong, N. Ningnuek, P. Praserthdam, J. R. Monnier, S. Assabumrungrat, React. Kinet. Mech. Catal., 2014, 112, 189-198.

[37] W. Wittanadecha, N. Laosiripojana, A. Ketcong, N. Ningnuek, P. Praserthdam, J. R. Monnier, S. Assabumrungrat, Appl. Catal. A, 2014, 475, 292-296.

[38] K. Tada, H. Koga, A. Hayashi, Y. Kondo, T. Kawakami, S. Yamanaka, M. Okumura, Bull. Chem. Soc. Jpn., 2017, 90, 506-519.

[39] H. G. Zhu, C. D. Liang, W. F. Yan, S. H. Overbury, S. Dai, J. Phys. Chem. $B$, 2006, 110, 10842-10848.

[40] M. Haruta, S. Tsubota, T. Kobayashi, H. Kageyama, M. J. Genet, B. Delmon, J. Catal., 1993, 144, 175-192.

[41] T. Honma, H. Oji, S. Hirayama, Y. Taniguchi, H. Ofuchi, M. Takagaki, AIP Conf. Proc., 2010, 1234, 13-16.

[42] H. Oji, Y. Taniguchi, S. Hirayama, H. Ofuchi, M. Takagaki, T. Honma, J. Synchrotron Radiat, 2012, 19, 54-59.

[43] B. Ravel, M. Newville, J. Synchrotron Radiat, 2005, 12, 537-541.

[44] A. L. Ankudinov, A. I. Nesvizhskii, J. J. Rehr, Phys. Rev. B, 2003, 67, 115120/1-115120/6.

[45] S. W. Weller, S. E. Voltz, J. Am. Chem. Soc., 1954, 76, 4695-4701.

[46] M. Gasgnier, L. Albert, J. Derouet, L. Beaury, A. Loupy, A. Petit, P. Jacquault, J. Alloys Compd., 1993, 198, 73-83.

[47] J. W. Walkiewicz, G. Kazonich, S. L. McGill, Miner. Metall. Proc., 
1988, 5, 39-42

[48] D. Kawamoto, H. Ando, H. Ohashi, Y. Kobayashi, T. Honma, T. Ishida, M. Tokunaga, Y.Okaue, S. Utsunomiya, T. Yokoyama, Bull. Chem. Soc. Jpn., 2016, 89, 1385-1390.

[49] F. Moreau, G. C. Bond, A. O. Taylor, J. Catal, 2005, 231, 105-114.

[50] M. Mihaylov, H. Knözinger, K. Hadjiivanov, B. C. Gates, Chem. Ing.
Tech., 2007, 79, 795-806.

[51] H. L. Tang, J. K. Wei, F. Liu, B. T. Qiao, X. L. Pan, L. Li, J. Y. Liu, J. H. Wang, T. Zhang, J. Am. Chem. Soc., 2016, 138, 56-59.

[52] M. Haruta, Gold Bull., 2004, 37, 27-36.

[53] Q. Yao, C. L. Wang, H. W. Wang, H. Yan, J. L. Lu, J. Phys. Chem. C, 2016, 120, 9174-9183.

\section{沉积-沉淀-微波干燥法制备金属氧化物负载的金簇合物及其在CO氧化和 硫化物氧化反应中的催化性能}

竹岁绚子 ${ }^{\mathrm{a}, \mathrm{b}}$, 石田玉青 ${ }^{\mathrm{a}, \mathrm{b}}$, 大桥弘范 ${ }^{\mathrm{c}}$, 本间彻生 ${ }^{\mathrm{d}}$, 春田正毅 $\mathrm{a}, \mathrm{b}, \mathrm{e}$, ,

a首都大学东京大学院都市环境科学研究科金化学研究中心, 南大泽1-1, 八王子市, 东京192-0397, 日本 b首都大学东京大学院都市环境科学研究科分子应用化学领域, 南大泽1-1, 八王子市, 东京192-0397, 日本

c福岛大学共生系统理工学类, 金谷川1, 福岛市, 福岛960-1296, 日本

d日本同步辐射研究所(JASRI), 光都1-1-1, 佐用, 兵库县679-5198, 日本

e 中国科学院大连化学物理研究所金催化研究中心, 辽宁大连116023, 中国

摘要: 采用沉积-沉淀法再辅以微波干燥和焙烧制备了金属氧化物负载的金簇合物和小的金纳米粒子. 干燥方法影响了金 颗粒尺寸. 在炉干燥过程中 $\mathrm{Au}(\mathrm{IIII})$ 因部分还原而致使 $\mathrm{Au}$ 聚集. 相反, 在微波干燥下, 因快速和加热均一而使 $\mathrm{Au}(\mathrm{III})$ 得以保 持, 在 $\mathrm{Al}_{2} \mathrm{O}_{3}$ 上负载的 $\mathrm{Au}$ 颗粒尺寸小至 $1.4 \mathrm{~nm}$. 该法可用于具有几种不同微波吸收效率的金属氧化物载体, 如 $\mathrm{MnO}_{2}, \mathrm{Al}_{2} \mathrm{O}_{3}$ 和 $\mathrm{TiO}_{2}$. 这些催化剂在低温 $\mathrm{CO}$ 氧化和硫化物选择有氧氧化反应中的催化活性比常规方法制备的更高.

关键词: 金纳米粒子; 金簇合物; 微波; 一氧化碳氧化; 有氧氧化

收稿日期: 2017-07-29. 接受日期: 2017-09-06. 出版日期: 2017-11-05.

*通讯联系人. 电话/传真: +81-42-677-2852; 电子信箱: haruta-masatake@center.tmu.ac.jp

基金来源: JSPS KAKENHI (日本学术振兴会, JP26810098, JP16K17943).

本文的电子版全文由Elsevier出版社在ScienceDirect上出版(http://www.sciencedirect.com/science/journal/18722067). 